\title{
Section:
}

\section{THE PSYCHOLOGY OF PERSONALITY}

\author{
NARRATIVE IDENTITY: FORMATION MECHANISM
}

\author{
LARYSA ZAHRAI
}

\begin{abstract}
The article discusses interpretations of identity from a postmodern perspective. A three-level model of personality is used to represent the methodological framework for analyzing identity. From a postmodern perspective, personal identity is defined as a socio-cultural representation. Narrative identity is formed through dialogic interaction, which results in the integration and internalization of life experience.
\end{abstract}

Keywords: identity, narrative identity, narrative method, narrative skills, postmodern perspective, reflection.

\section{INTRODUCTION}

The unstable modern world adds a particular urgency to issues of personality, which undergoes crises, changes, acquires new characteristics and subsequently changes the world. Such an interpretation of personality development is suggested by postmodernism and is a mark of the present time. A plurality of ideas, ideologies, and cultural contexts is the postmodern environment in which a personality has to settle, self-actualize, and acquire a sense of self-sameness, identity. This requires exploring the notions of personality and identity from postmodern perspectives and finding new approaches to studying the "me" of the modern individual.

Personality as a phenomenon is conceptualized differently in various theories, for instance as an energy system in psychoanalysis. Its essence lies in revealing the libido, instincts, aggressive impulses. However, in social theories, transactional analysis, personality is regarded as the sum of total roles an individual plays. Social cognitivists, behaviorists associate personality with an information processor when it is a system of parts connected by cause-and-effect relationships. In trait theories, personality is regarded as a system of various traits which determine a person's behavior. Thus the Big Five Theory (Costa \& McCrae, 1995) suggests that personality consists of dimensions such as extraversion, which determines interpersonal interaction; neuroticism, whose level indicates stress resistance; openness to experience, which manifests itself in readiness to changes; agreeableness, which reflects attitude to others; and conscientiousness, which is associated with purposefulness and persistence [5]. However, personality has always been and will always be a multidimensional system extending far beyond traits.

The postmodern epoch has generated novel insights into the nature of personality. Personality is viewed as continually evolving, developing. According to G. Kelly's Personal Construct Theory, an individual is actively engaged in constructing and exploring their own world, building theories about it, reflecting on their life, interpreting events, creating constructs which reflect their categorization experience and awareness of themselves, of others, and of the world as a whole. The new "me" is 
dynamic, continual, aware of being influenced by others, slow in construing its individual image, its text. It tries to be contextual, to fit in certain frames of understandability [2, p. 10]. Such a "me" is construed due to communicative processes and thus is linguistic by nature, not biological, psychological or cognitive. It is this idea that pervades social constructivism, which belongs to the postneoclassical tradition. A person is interpreted as a social construct involved in complex social processes where language is both a product and a producer of reality. According to the Sapir-Whorf hypothesis, a person's view of the world is language-specific, and linguistic categories determine cognitive categories. Therefore, a person's language reflects their views, experience created out of senses, concepts, constructs. It is from such a perspective that I will try to describe the phenomenon of identity, its place in personality structure and will outline novel research approaches to the "me" of the modern individual who is faced with a crisis of identity, particularly in adolescence.

The article is aimed at discussing interpretations of identity from a postmodern perspective, defining narrative identity, and exploring its formation mechanisms.

\section{ANALYSIS AND Discussion}

As researchers (McAdams \& Pals) note, personality is now faced with the so-called identity crisis a search for self, own identity, which thereby leads to changes in the formation of personal identity. The latter is described as a multiple phenomenon with unclear boundaries and changeable characteristics.

In order to explore the phenomenon of identity, it is necessary to differentiate between personality and identity, which, in my opinion, must be done by relying on the three-level model of personality (McAdams \& Pals, 2006) composed of five traits (the Big Five personality traits) [7; 10; 12]. The threelevel model is not a psychological theory per se in that it does not identify cause-and-effect relationships among and inside the tree levels. Rather, the model serves as a framework for organizing various aspects of personality in a conceptual space [14, p. 66-72]. On the basis of such a model, let us consider these dimensions in greater detail. At the first, basic, level of personality, the traits are relatively decontextualized and describe individual differences. The Big-Five Trait Taxonomy (extraversion, neuroticism, openness to experience, agreeableness, conscientiousness) has become widely used for reflecting individual differences, as shown in a highly generalized model [6, p. 33-58]. The second level is composed of characteristic adaptations, which are more contextualized aspects of personality (concrete life contexts and ideological conditions). They manifest themselves in everyday life, reflecting motivational, socio-cognitive aspects of personality, goals and self-expression strategies formed in line with socio-cultural demands. The third level reflects an individual's subjective life story. It is a level of self-awareness. Unlike dispositional traits (Level I) and characteristic adaptations (Level II), integrative life narrative (Level III) in terms of determines the complex and contextual ways in which traits and characteristic adaptations manifest themselves in specific, yet potentially predictable, life events [9, p. 132-138]. Therefore, the third level of the model is a highly idiographic level of personality: it reveals a person's truly unique experience which secures them a sense of self-sameness, identity. The idiographic level of personality is based on the principles of the humanistic approach described by J. Bugental as follows: 1) a holistic approach to viewing a human being; 2) existential psychotherapy; 3) primary attention to a person's subjective, lived experience; 4) dominance of a person's values and meanings; 5) emphasis on the importance of unconditional positive regard; exploring self-actualization and formation of higher human characteristics; 6) past experiences cannot be determining factors of personality; 7) flexibility of research methods aimed at studying personality. The idiographic level of personality involves an analysis of characteristics which determine uniqueness, originality and holisticism. The main methods used to research this level are reflections and descriptions of individual cases, with data being theoretically generalized and interpreted.

Thus it is possible to research identity on the basis of individual experience and by applying corresponding techniques, for instance narrative methods. Identity is a much more definite aspect of the "me" called personal identity. It is defined as awareness of one's own originality, uniqueness of one's life experience, which determines self-sameness. Personal identity should be regarded as a result 
of the integration of self, which is not reduced to a sum of identities acquired in childhood. In the course of self-integration, the main role is played by reflective self-awareness because it develops the holistic "me", which is so crucially important for personality. Reflection is a process of exploring self, own internal mental acts and states. Reflexivity is a major characteristic of the human mind, which enables its normal activity. As E. Kurnosikova notes, researchers distinguish between intellectual and personal reflection. The former develops mindsets, assumptions, assertions; the latter performs the functions of self-evaluation and motivation. Personal reflection is directed at an individual's "me", at understanding their meanings, attitudes, conflicts.

The function of reflection is to make the human "me" the object of self-discovery and selfmanagement. In such a way a person becomes aware of their characteristics and abilities, evaluates their significance. During this process, another individual also serves as an object because discovering characteristics of another person and comparing them with their own ones enables a person to identify the boundaries of their "me", their inner world, and to understand their own differences from others. Due to reflection, an individual interprets certain social norms, attaches personal meaning to them thus gaining life experience, performs the so-called filtration of images and identification models which circulate in an individual's interpersonal space and creates original ones, which makes personality unique and inimitable [1]. In other words, reflection determines the formation of narrative skills, interpretative competence (the ability to interpret identification patterns and attach personal meaning to them). Personal identity is defined as a socio-cultural representation designed and organized as a certain cognitive structure. According to N. Chepeleva, narratives can be regarded as such cognitive structures [3, p. 5-15]. It is narratives that serve as interpretations of socio-cultural world and enable a person to construct their own inner mental activity thereby reflecting personal identity. For this reason, M. Mair argues that it is important to take into account cultural and contextual stories as well as individuals' stories. Cultural stories determine the shape of our individual life narratives. People perceive their lives through stories - through cultural, innate, narratives and through personal narratives which they construct on the basis of cultural narratives. A model of a life story is a model of identity because a personal story gives significance to one's experience and performs a particularly important role in identifying the "me". A life story combines various episodes in a certain coherent pattern. The coherence of a life story makes life events significantly more meaningful. Hence, the development of a stable sense of identity is based on a person's ability to participate in dialogue and create coherent narratives. Such a shift in interpreting identity enables to consider narrative identity, which manifests itself only in the course of narrating stories. Thus in order to define identity, it is necessary to hear a "Who I Am" story, which contains a reconstructed past, perceived present, and imaginary future, giving a person a sense of unity and meaningfulness [12, p. 211-217].

People create identity by integrating their life experience into internalization, which creates a story about them and gives them a sense of self-sameness. Through narrative identity, people communicate to themselves and others who they are now, how they achieved that and where they think their lives will be going in the future. The idea that people create identity by making stories about their lives has emerged during the last two decades as a broadly integrative conception both in the humanities and the social sciences [12]. In psychology, empirical studies explore a connection between the internal dynamics of a private life story and certain psychological characteristics. Thus a link was found between personal maturity (more points were gained for independent indicators) and the ability to give detailed descriptions of experiencing loss and struggle [13]. Individuals who scored high on psychological maturity produced narratives which emphasized learning, growth and positive personal transformation. K. C. McLean and M. W. Pratt (2006) found that young people who gave detailed descriptions of turning points in their lives tended to gain higher scores for the overall index of maturity. Numerous studies show that plots with positive outcomes of negative, problematic events in narratives are associated with higher levels of happiness and self-consciousness (for instance King \& Hicks, 2007; Lilgendahl \& McAdams, 2011). R. Tavernier and T. Willoughby (2012) argue that students who find positive sense in their narrations about difficult life spans show higher levels of psychological well-being. Psychotherapy patients who told stories which emphasized their ability to control their 
world and take independent decisions eventually showed a corresponding reduction of symptoms and improvement of mental health [4, p. 367-370].

Narrative identity emerges in adolescence, partly as a function of societal expectations regarding identity and as a result of the maturation of formal operational thinking. T. Habermas and S. Bluck (2000) note that it is not until adolescence that people can construct stories about their lives that exhibit cause-and-effect connections and thematic coherence. In line with these findings, other studies suggest that as people approach adulthood, their life narratives display causal coherence, thematic coherence, and other characteristics of a well-formed narrative identity (Habermas \& de Silveira, 2008). Identity as a durable sense of inner sameness and as a feeling of being similar to other people appears in late adolescence. Faced with a crisis in adolescence, individuals develop their identity by gradually synthesizing all their identities, abandoning old roles, and systematizing acquired behavior patterns in the course of self-identification. All these roles are integrated into a single whole, conceptualized, connected with the past and projected onto the future. This process is effectively enhanced by reflection and narrative, which serve as a foundation for building narrative identity.

Narrative identity builds slowly as people tell stories about their experiences to and with others. Selves create stories, which in turn create selves [13, p. 135-137]. As K. Weingarten writes, "the experience of self exists in the ongoing interchange with others ... the self continually creates itself through narratives that include other people who are reciprocally woven into these narratives" [15, p. 289]. For this reason, a personal narrative identity should be interpreted as a textual mode of personal identity, with self-awareness (created and maintained ego-identity) and self-representation (created and maintained social identity) being simultaneous processes which build a single construct. Thus identity refers to the way of constructing the "me" and interacting with the world and significant others on the basis of reflective processes and interpretations, which exhibits a unity of personal and social identity.

Through repeated interactions with others, stories about personal experiences are processed, edited, reinterpreted, retold, and subjected to a range of social and discursive influences because the storyteller gradually develops a broader and more integrative narrative identity. To develop a narrative identity, a person must first learn how to share stories in accord with particular cultural parameters and within particular groups - in families, with peers, and in other formal and informal social contexts. R. Fivush and C. A. Haden argue that conversations with parents about personal events are critical to the development of narrative skills in children and have a positive effect on the formation of an adolescent's identity. When important people in a person's life agree with his or her interpretation of a personal story, he or she is likely to hold on to that story and to incorporate it into his or her more general understanding of who he or she is and how he or she came to be. There is a body of research (K. C. McLean, A. Breen, M. A. Fournier, M. Pasupathi, C. Wainryb) confirming that narrative skills and interpretive narration boost personality development in adolescence. Such children find it easier to overcome adolescence crisis, which results in developing adequate identity, self-identity. Adequate identity is an integrated image of all knowledge about self based on past experience and future projections. The narratives of such adolescents emphasize positive evaluations of norms, ideals held by their parents and significant others as well as institutions. A crisis of identity can be exacerbated manifesting itself in the inability to make a choice among identification models, which leads to inadequate behavior, psychological tension, negative emotions, the inability to become aware of the image of self and experience self-sameness.

Such crises can result in dangerous consequences such as loss of predictability, increased passivity or vice versa in feverish activeness, aggression, rage, which is a natural consequence of an adolescent's disorientation, anxiety, fear. During such periods, an individual's adaptability depends on their personal identity development level, which is the backbone for self-identification [1], on their ability to rethink old self-narratives and construct new ones, as well as on their narrative skills.

J. Marcia suggests the following personal identity statuses depending on how an individual faces a crisis and what values and beliefs he or she pursues: 1) identity diffusion, which applies to individuals who have no professional, familial or other models of their future and little commitment to 
independent life decisions; 2) identity foreclosure, which characterizes individuals who make decisions about the future under the pressure of the surroundings, not as a result of reflection; 3) identity moratorium, which marks people who are experiencing a crisis and thus postponing important decisions for an uncertain time; 4) identity achievement, which refers to people whose new life-making decisions are made consciously and independently as a result of dealing with an identity crisis. In my opinion, this typology builds a basis for identifying parameters for researching narrative identity. A person with diffused identity is unable to construct narratives about the future; the past can be presented as an enumeration of events without emphasis on overcoming obstacles, resolving urgent problems, which is a sign of lack of readiness to make decisions and fight crises and is characterized by maladaptation. Identity moratorium manifests itself as a person's failure to make narratives about a future filled with goals, plans, expectations, endeavors; and as a person's tendency to postpone goal achievement plans or decisions to solve career, family or other problems. The narratives of such individuals do not contain descriptions of the dynamic "me", which reflects social statuses and roles. Identity foreclosure is diagnosed in individuals who produce stereotypical, reproductive narratives about making important decisions in various spheres of activity; however, such narratives lack analysis and insight, which is a sign of immature narrative skills. Identity achievement is possible in individuals who construct narratives about being ready to make decisions based on critical thinking, reflection, selfanalysis.

Therefore, a study of identity involves a person's unique experience, which secures them a feeling of self-sameness. Hence, the narrative method is used as the main one. A narrative is a deeply idiographic, dynamic reflection of how people recollect their experience. This raises the question of how objective this method is since narratives about life are not necessarily truthful or accurate. Thus, in my opinion, there are serious reservations about the effectiveness of narrative methods. All autobiographical recollections, accounts of personal experiences provide a dynamic reconstruction of images of events. A story is a highly idiographic, dynamic reflection of how people recall their past and what function it performs. The purpose of narrative research is to understand these functions and their connection with the other correlates and outcomes, not with the truthfulness of recollections. Narratives are subjective constructions which carry objective consequences. For instance, individual differences in autobiographical narratives and plot development mark successful resolutions of inner conflicts or gender stereotypes, changes in the mental health of psychotherapy clients. Since narratives are deeply embedded in socio-cultural interaction, the way people tell about their lives reflects meaning construction [8, p. 305]. Therefore, narrative approaches to identity are not reducible to self-report measures, but rather represent a different level of analysis that assesses subjectivity in unique ways [4]. Narratives allow researchers to ethically and meaningfully understand lived experiences in context [8, p. 305].

In fact, a research employing narrative methods is one based on reasoning. Therefore, an empirical study of narratives is one about subjectivism since it uses tools for exploring issues of subjective, personal importance. Hence, narrative methods are particularly suitable for studying meaning-making processes with regard to identity.

\section{ConCLusions}

Therefore, from a postmodern perspective, personal identity is defined as a socio-cultural representation organized as a cognitive structure in the form of a narrative. In the three-level model of personality, identity occupies the third, idiographic, level since a sense of self-sameness arises out of integrated individual experience. A sense of identity develops on the basis of an individual's ability for dialogic interaction, which results in coherent narratives. Being narrative in nature, identity is built in the course of constructing life stories by incorporating life experience into an internalized, evolving story of the self.

Narrative identity emerges in adolescence due to the development of formal operational thinking, which triggers the reflexive mechanisms of self-consciousness and narrative skills. Due to such 
mechanisms, an adolescent makes sense of and integrates self-knowledge, which is based on their identification experience and contains ideas about the future. By telling their life stories, an adolescent creates their identity and establishes an adequate personal identity, which indicates a constructive resolution of adolescence crisis.

The narrative method is mostly employed to research identity because it allows studying a person's contextual experience, ways of building and integrating it. The purpose of the narrative method is to explore experience not only in terms of its nature, but also its functions and significance.

\section{REFERENCES}

[1] Заграй А.Д. Пошук ідентичності у період суспільних трансформацій. Вісник Одеського національного університету. Серія : Психологія, 20 (1(35)) (2015), 32-40.

[Zahrai L.D. Poshuk identychnosti u period spilnykh transformatsii. Visnyk Odeskoho natsionalnoho universytetu. Seriia: Psykholohiia, 20 (1(35)) (2015), 32-40.]

[2] Титаренко Т.М. Сучасна психологія особистості: Навч. посібник. 2-е вид. Київ, 2013.

[Tytarenko T.M. Suchasna psykholohiia osobystosti: Navch. posibnyk. 2-e vyd. Kyiv, 2013.]

[3] Чепелева Н.В. Идентичность личности в контексте психологической герменевтики. Актуальні проблеми психології. Психологічна герменевтика, 2 (4) (2006), 5-15.

[Chepeleva N.V. Identichnost lichnosti v kontekste psikhologicheskoi germenevtiki. Aktualni problemy psykholohii. Psykholohicha hermenevtyka, 2 (4) (2006), 5-15.]

[4] Adler J.M. Living into the story: Agency and coherence in a longitudinal study of narrative identity development and mental health over the course of psychotherapy. Journal of Personality and Social Psychology, 102 (2) (2012), 367-389. doi: 10.1037/a0025289

[5] Costa Jr.P.T., McCrae R.R. Domains and facets: Hierarchical personality assessment using the Revised NEO Personality Inventory. Journal of Personality Assessment, 64 (1) (1995), 21-50.

[6] DeYoung C.G. Cybernetic big five theory. Journal of Research in Personality, 56 (2015), 33-58. doi: 10.1016/j.jpr.2014.07.004

[7] Dunlop W.L. Contextualized personality, beyond traits. European Journal of Personality, 29 (3) (2015), 310-325. doi: 10.1002/per.1995

[8] Fivush R., Merrill N. An ecological systems approach to family narratives. Memory Studies, 9 (3) (2016), 305-314. doi: 10.1177/1750698016645264

[9] Josselson R., Flum H. Identity status: On refinding the people. In: McLean K.C., Syed M. (Eds.) The Oxford handbook of identity development. Oxford University Press, New York, 2015, 132-147.

[10] Lilgendahl J.P. The Dynamic Role of Identity Processes in Personality Development: Theories, Patterns, and New Directions. In: McLean K.C., Syed M. (Eds.) The Oxford handbook of identity development. Oxford University Press, New York, 2015, 490-507.

[11] McAdams D.P. The psychological self as actor, agent, and author. Perspectives on Psychological Science, 8 (3) (2013), 272-295. doi: 10.1177/1745691612464657

[12] McAdams D.P., Pals J.L. A new Big Five: Fundamental principles for an integrative science of personality. American Psychologist, 61 (3) (2006), 204-217. doi: 10.1037/0003-066X.61.3.204

[13] McLean K.C., Pasupathi M. Old, new, borrowed, blue? The emergence and retention of personal meaning in autobiographical storytelling. Journal of Personality, 79 (1) (2011), 135-164. doi: 10.1111/j.1467-6494.2010.00676.x

[14] Syed M. Advancing the cultural study of personality and identity: models, methods, and outcomes. Current Issues in Personality Psychology, 5 (1) (2017), 65-72. doi: 10.5114/cipp.2017.66604

[15] Weingarten $\mathrm{K}$. The discourses of intimacy: Adding a social constructionist and feminist view. Family Process, 30 (3) (1991), 285-305. doi: 10.1111/j.1545-5300.1991.00285.x 
Address: Larysa Zahrai, Vasyl Stefanyk Precarpathian National University, 57 Shevchenko St., IvanoFrankivsk, 76025 Ukraine.

E-mail: todoriv_larisa@i.ua

Received: May 6, 2020; revised: August 8, 2020.

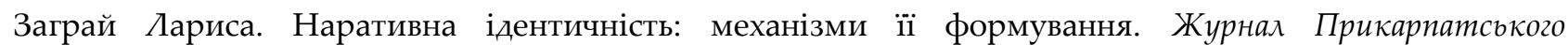
університету імені Василя Стефаника, 7 (2) (2020), 85-91.

У статті розгдянуто проблему трактування ідентичності у постмодерних проекціях. Аналізуються відмінності між феноменами особистість та ідентичність. На основі трирівневої моделі особистості, що організовує різні аспекти особистості в концептуальному просторі і включає перший рівень - індивідуально-психологічні властивості особистості, другий рівень - адаптаційні можливості особистості та третій рівень - інтегрований індивідуальний досвід июдини, що забезпечує їй відчуття самототожності, ідентичності, розкривається методологічний (ідіографічний) ракурс аналізу ідентичності. Метою статті $є$ розкриття феномену «ідентичності» у постмодерному трактуванні; визначенні поняття “наративна ідентичність" та механізмів пї формування. У постмодерному трактуванні персональна ідентичність визначається як соціокультурна репрезентація, яка організована як когнітивна структура у вигляді наративу. Наративна ідентичність формується у процесі діалогічної взаємодії, у результаті якої інтегрується та інтераналізується життєвий досвід. Визначено механізми формування наративної ідентичності у підлітковому віці - рефлексивні механізми самосвідомості (наративні навички), які забезпечують інтегрування різних аспектів, характеристик «Я». Ідентичність трактується як текстовий модус існування особистості, де самозрозуміння (его-ідентичність) і самопред'явлення (соціальна ідентичність) відбуваються одночасно, утворюючи єдиний конструкт. Визначено параметри дослідження наративної ідентичності: наявність/відсутність перспективи, готовність/не готовність до прийняття рішень, наявність/відсутність динамічного «Я». Розкрито доцільність застосування наративних методів у дослідженні ідентичності.

Кдючові слова: ідентичність, наративна ідентичність, наративний метод, наративні навички, постмодерна проекція, рефлексія, рефлексивні механізми самосвідомості. 